ficulties of taking into account the comparative purchasing power of currencies outside the Organisation for Economic Cooperation and Development, + and the countries' large "black economy." But people in most types of occupation, both manual and non-manual, seem to work in the black economy. Relative deprivation was seen not necessarily in relation to direct income distribution but in relation to privileges such as the ability to travel abroad or access to Western goods, privileges that in the West are related to income.

Eastern Europe will be a testing ground for Wilkinson's hypothesis in view of the introduction of market forces, which will widen income differentials appreciably.

D P FORSTER

Division of Epidemiology and Public Health,

School of Health Care Sciences,

University of Newcastle upon Tyne Medical School,

Newcastle upon Tyne NE2 $4 \mathrm{HH}$

1 Wilkinson RG. Income distribution and life expectancy. $B M \mathcal{Y}$ 1992;304:165-8. (18 January.)

Boys RJ, Forster DP, Józan P. Mortality from causes amenable and non-amenable to medical care: the experience of eastern Europe. BMF 1991;303:879-8

3 Józan P. Studies in mortality differentials: an ecological study of mortality differentials in Budapest. Part 1. Budapest: Central Statistical Office, 1987

4 Parkin D. Comparing health service efficiency across countries. Oxford Review of Economic Policy 1989;5:75-88.

\section{Bone banks}

SIR, - H I Atrah's proposal that bone banks should be developed by the national blood transfusion services ${ }^{1}$ will be warmly welcomed by those who have recently expressed concern at the lack of tissue banking facilities in the United Kingdom compared with Europe and North America. ${ }^{2}$

About 18 months ago the directors of the Scottish National Blood Transfusion Service concluded that it would be in patients' best interests if tissue banking, starting with bone banking, was developed on a national (Scottish) basis within the transfusion service's centres. This programme has now been fully commissioned, and bone banking is a feature throughout Scotland. There is little doubt that the regional blood transfusion centres' skills with regard to good manufacturing practice for biological agents for therapeutic use have played a major part in securing a rapid and successfu outcome to the first phase of this coordinated development of tissue banking nationally. Success would not have been possible without the enthusiastic collaboration of local orthopaedic surgical teams.

Further plans are now emerging for an integrated programme of multitissue banks in the regional transfusion centres in Scotland. The support of the British Blood Transfusion Society, which might encourage the creation of a special interest group directed towards tissue banking, would also be an important contribution to this development.

J D CASH

Sational Blood Transfusion Service,

Edinburgh EH17 70'

Atrah HI. Bone banks. BM7 1992;304:68. (11 January.)

2 Phillips GO. Tissue banking in Europe. Lancet 1991;338:1514-5.

\section{Organ donation from intensive care units}

SIR, - Sheila M Gore and colleagues' audit of organ donation from intensive care units shows that much can be done to increase the number of organ donors from such units.' The authors, quite rightly, state that age is no limit to corneal donation. We wish to emphasise that corneas can be donated up to 24 hours after death and can be easily retrieved by the local ophthalmologist from donors in the mortuary or other place of rest. This is not the case with the other organs mentioned in the audit and means that there is a much larger number of potential corneal donors outside in tensive care units. In Greater Manchester last year 122 corneas were donated, of which only 22 came from intensive care units or through transplant coordinators

The only principal exclusions for corneal donation are transmissible infections such as HIV and hepatitis $\mathrm{B}$ virus infections. Previous corneal disease and ocular surgery may make the cornea unsuitable for transplantation, but such eyes are still extremely valuable for research into ocular disease. If these facts were known by all medical practitioners and staff dealing with dying patients and the recently bereaved the number of corneal donations could increase considerably. Often the potential for corneal donation is overlooked when other organs are unsuitable for donation because of the patient's age or coexisting disease or malignancy. Nationally coordinated eye banks and associated scientific staff can assess donated corneas for freedom from infection and tissue quality. The fact that corneal donation can go towards salvaging the sight of many potentially blind patients is often a great comfort to the relatives of the person who has died.

J KWARTZ A E A RIDGWAY A B TULLO

David Lucas Eve Bank,

Manchester Roval Eve Hospital

Manchester Royal Eye

1 Gore SM, Cable DJ, Holland AJ. Organ donation from intensive care units in England and Wales: two year confidential audit of deaths in intensive care. BMF 1992;304:349-55. (8 February.)

SIR, - The confidential audit of intensive care deaths in England and Wales initiated by the Department of Health has further clarified the means by which organ donation can be increased.' As only $6 \%$ of families of potential donors were not asked about organ donation, required request legislation would have little impact. Sheila M Gore and colleagues suggest that an increase of up to $7 \cdot 7 \%(100 / 1300)$ in organ donation could be achieved by reducing delays in the performance of tests for brain stem death. Other recent studies have shown a larger potential increase from increasing the number of patients being ventilated but this would have important implications for resources. ${ }^{2}$

The Department of Health's audit shows how opt out legislation would result in a considerable increase in organ donation. Allowing for a $2 \%$ opt out rate (as in Belgium), an increase in organ donors of $32 \cdot 8 \%$ ( 630$)$ would have been produced.

We must hope the Department of Health appreciates the importance of its own audit and strives to reduce the waiting list for organ transplants with the same enthusiasm as waiting lists for minor surgical procedures.

B RHODES

\section{Alder Hey Children's Hospital,} Liverpool L12 $2 \mathrm{AP}$

1 Gore SM, Cable DJ, Holland AJ. Organ donation from intensive care units in England and Wales. B.MF 1992;304:3+9-55.

2 Feest TG, Riad NH, Collins CH, Golby MGS, Nicholls AJ,

Hamad SN. Protocol for increasing organ donation after cerebrovascular death in a district general hospital. Lance 1990;335:1133-5.

3 Salih MAM, Harvey I, Frankel S, Coupe DJ, Webb M, Cripp HA. Potential availability of cadaver organs for transplantation. BMF 1991;302:1053-5.

SIR,-Sheila M Gore and colleagues' paper reporting their audit of deaths and organ donations in intensive care units ${ }^{1}$ should, at last, lay to rest previous allegations that large numbers of potential donors in intensive care units were being missed.
The part of their conclusion relating to a reduction in relatives' refusal is correct but that suggesting prompter testing of brain stem death is questionable. Delays relate to the initiation of tests and the interval between them. In my experience in several British hospitals the first and second sets of tests are generally carried out within one to three hours of each other.

The practicalities of initiating tests are related to several factors, which may not be apparent to those who do not perform them. There is no way of ensuring that effects of sedative, analgesic, and anaesthetic drugs have passed other than by waiting for an adequate period. ${ }^{3}$ This period is open to clinical opinion, and staff must therefore err on the side of caution. The difficulties in predicting outcome after brain injury, particularly in younger patients, lead to wide variation in the duration of active management.

Tests should be seen to be done after careful consideration of the patient during the daytime, which effectively rules out at least 12 hours of any day. Equally importantly, discussions with relatives, who increasingly are delayed by travelling long distances, are best carried out in dayligh hours. Confidence in tests is improved, among less informed observers, if they are seen to confirm brain stem death in most cases. In many cases the patient's hopeless prognosis is evident from the outset and any treatment is probably as much for the benefit of relatives and other attending staff as for the patient. In such cases a delay allows them time to appreciate the situation fully, and in this period the relatives' response to requests for organ donation may change from being initially negative to positive.

Careful handling of relatives, who in a distressed state may beome aggressive and confused, is essential if bad publicity related to occasional cases is to be avoided. A perception that tests are performed too promptly may repeat the fiasco of 1980, when adverse publicity on Panorama produced a pronounced decline in organ donation ${ }^{+}$

Department of Anaesthesia,

A BODENHAM

(ieneral Infirmary,

Leeds LS1 3EX

1 Gore SM, Cable DJ, Holland AJ. Organ donation from intensive care units in England and Wales: two year confidential audit of deaths in intensive care. BMF 1992;304:349-55. (8 February.) Chisholm GD. Time to stop the softly softly approach on organ for transplantation. $B M \mathcal{F}$ 1988;296:1419-20.

3 Bodenham A, Park GR. Care of the multiple organ donor. Intensive Care Med 1989:15:340-8.

B 1980;ii:1258-9.

5 Pallis C. Medicine and the media. BMf 1980;281:1064.

\section{Rationing}

SIR, - Unfortunately, as it reads like "three cheers for rationing," Richard Smith's editorial could be misunderstood by managers and the lay public. 'It misleads them further by conflating three different kinds of rationing - that entailed in clinical decisions to withhold treatment in certain cases; that entailed in planning priorities in the NHS; and that now advocated in disqualifying, not on clinical but on economic grounds, whole groups of people from the treatment they need and, in plain words, consigning them to death or unrelieved invalidism

Perhaps bemused by "democracy in all its messy splendour," Smith idealises the capacity of nurses, managers, and the public to make judgments with regard to all three types of rationing. Unfashionable as it is to say that doctors know best, they still do often know better than anyone else, including philosophers and economists, about these matters.

It is a cliché, since Foucault, to say that all "disciplines" are influenced by ideology. When economists - for example, Cam Donaldson and Gavin Mooney, writing on needs assessment and 
priority setting ${ }^{2}$ - show that we should not waste our few pence on renal dialysis when chiropody is more value for money or when they come up with the breathtaking news that, given its head, the health service could consume the entire gross national product it is not a sober professional judgment but merely an ideological proclamation with no other relevance. Similar proclamations could be made about education to perpetuate squalid classrooms and the squeezing of universities.

Rationing is a cosy word, with overtones of fair play and wartime Britain, but, the world over, when it really bites and to the bone (which it never did in Britain) it leads to ugly corruption and black markets. Actually, Smith's editorial is inadvertently about rationing the poor, the inarticulate, and the common run of citizens. The wealthy and the establishment, the enterprising, and the organised crime mob will never be rationed, whatever the rules invented by economists and philosophers, while privilege and corruption in the supply of medical services will leak and pollute society as a whole.

Smith simply overlooks the corrosive effect on doctors and their ethics that rationing on nonclinical grounds may well have. What kind of damaged profession with market style doctors can we expect with the next generations increasingly educated in an atmosphere of spurious economic indices, where cost effectiveness is all and devil take the hindmost? And into what byways will medical research be diverted? He admires the rationing exercise in Oregon as if it did not spring from the fact that medical rationing in the United States is brutal and always has been.

Certainly, health services have to be planned amid a maze of conflicting demands, but that is no excuse for letting loose gungho solutions like rationing-denying the sick their treatment on the basis of supposedly general principles defined by managers, philosophers, and economists, of all people, and by public opinion polls. Surely, the journal should take the lead in scepticism not only about rationing but about the impossibility of decently funding the NHS, and it should not get lost in ideologically inspired pseudosolutions to its mounting debility. Much less should the editor, over impressed by Oregon, eagerly promote the dissolution of its soul.

HAROLD BOURNE

00136 Rome,

Italy

1 Smith R. Rationing: the search for sunlight. BMF 1991;303 1561-2. (21-28 December.)

2 Donaldson C, Mooney G. Needs assessment, priority setting, and contracts for health care: an economic view. BMJ 1991;303 1529-30. (14 December.)

\section{Advice on foreign travel is not health promotion}

SIR, - For some years our nurses have been telling patients travelling abroad how to avoid getting ill while they are away. There is a lot to cover: sensible precautions against food poisoning, avoiding excessive exposure to the sun, malaria, and so on. Most importantly now, the nurses specifically discuss the risk of HIV infection.

Under the new contract we were able to count this 15 minute consultation as part of a health promotion clinic. Our family health services authority has now told us that advice on foreign travel no longer counts as health promotion. Sadly, we will therefore not have time to discuss these issues properly with our patients. All we can do is give them the Department of Health's leaflet "Health Advice for Travellers" and hope that they read it.

We are paid $£ 4.50$ per patient for health promo tion. We would probably need to prevent only one case of AIDS per 10000 patients seen to be cost effective. Perhaps the Department of Health could explain why it would rather spend this money treating AIDS instead of preventing it.

PATRICK BOWER

London SW $128 \mathrm{EA}$

\section{Euthanasia around the world}

SIR,-Did the news items on euthanasia around the world imply a change in the position of the $B M F$ in line with other professional opinion worldwide,' as indicated for instance by the reports of the Institute of Medical Ethics ${ }^{2}$ and the Remmelink Commission?

A corresponding shift in public attitudes has been measured objectively by market research organisations in polls repeating the same question over time. In Britain National Opinion Poll found that agreement with the statement "Some people say that the law should allow adults to receive medical help to an immediate peaceful death if they suffer from an incurable physical illness that is intolerable to them, provided that they have previously requested such help in writing" rose from $69 \%$ (95\% confidence interval $67 \%$ to $71 \%)$ in 1976 , through $72 \%(70 \%$ to $74 \%)$ in 1985 , to $75 \%$ $(73 \%$ to $77 \%)$ in 1989 . Similarly, in the United States the Roper Organisation's question "When a person has painful and distressing terminal disease, do you think doctors should or should not be allowed by law to end the patient's life if there is no hope of recovery and the patient requests it?" elicited support from $62 \%(60 \%$ to $64 \%)$ in 1986 , increasing to $68 \%(66 \%$ to $70 \%)$ in 1991 .

Evidence from Canada and Australia is available over a longer timescale and is therefore more compelling (tables I and II). It shows a trend that it would be imprudent to ignore. Though medicine should take a note of the views of three quarters of the population, however, it also needs a clear legal framework. Active euthanasia is an act of pre-

TABLE I-Response of people aged 18 and over in Canado to question "When a person has an incurable disease that causes great suffering do you, or do you not, think that competent doctors should be allowed by law to end the patient's life through mercy killing if the patient has made a formal request in writing?"

\begin{tabular}{|c|c|c|c|c|}
\hline \multirow[b]{2}{*}{ Year } & \multirow{2}{*}{$\begin{array}{c}\text { No } \\
\text { sampled }\end{array}$} & \multicolumn{3}{|c|}{$\%$ Replying $(95 \%$ confidence interval) } \\
\hline & & Yes & No & Undecided \\
\hline & 705 & 45 (41 to 49 ) & 43 (39 to 47$)$ & $12(10$ to 1 \\
\hline 197 & 1047 & $55(52$ to 58$)$ & 35 (32 to 38$)$ & $10(8$ to 12$)$ \\
\hline 197 & 1031 & $68(65$ to 71$)$ & 23 (20 to 26 ) & $9(7$ to 11$)$ \\
\hline 198 & 1050 & $66(63$ to 69$)$ & 24 (21 to 27$)$ & 10 (8 to 12$)$ \\
\hline 1989 & 1029 & $77(74$ to 80$)$ & $17(15$ to 19$)$ & $6(5$ to 8$)$ \\
\hline 1990 & 1051 & $78(76$ to 81$)$ & $14(12$ to 16$)$ & $8(6$ to 10$)$ \\
\hline
\end{tabular}

Poll commissioned by a group of Canadian newspapers and conducted by Gallup Canada, of Toronto.

TABLE II-Response of people aged 14 and over in Australia to question "If a hopelessly ill patient in great pain with absolutely no chance of recovering asks for a lethal dose, so as not to wake again, should the doctor be allowed to give the lethal dose or not?"

$\%$ Replying ( $95 \%$ confidence interval)

\begin{tabular}{|c|c|c|c|c|}
\hline \multirow[b]{2}{*}{ Year } & \multirow[b]{2}{*}{$\begin{array}{c}\text { No } \\
\text { sampled }\end{array}$} & \\
\hline & & $\begin{array}{l}\text { Give lethal } \\
\text { dose }\end{array}$ & No lethal dose & Undecided \\
\hline 1962 & 2000 & $47(45$ to 49$)$ & 39 (37 to 41$)$ & $14(13$ to 16$)$ \\
\hline 1978 & 1800 & $67(65$ to 69$)$ & $22(20$ to 24$)$ & $11(10$ to 12$)$ \\
\hline 1983 & 1057 & $67(64$ to 70$)$ & 21 (19 to 24$)$ & $12(10$ to 14$)$ \\
\hline 1986 & 1117 & $66(63$ to 69$)$ & $21(19$ to 23$)$ & $13(11$ to 15$)$ \\
\hline 1987 & 1100 & $75(72$ to 78$)$ & $18(16$ to 20$)$ & $7(6$ to 9$)$ \\
\hline 1989 & 1191 & $71(68$ to 74$)$ & 20 (18 to 22$)$ & $9(7$ to 11$)$ \\
\hline 1990 & 1160 & $77(75$ to 79$)$ & $17(15$ to 19$)$ & $6(5$ to 7$)$ \\
\hline 1991 & 1257 & $73(71$ to 76$)$ & $20(18$ to 22$)$ & $7(6$ to 8$)$ \\
\hline
\end{tabular}

Poll commissioned and conducted by Morgan Gallup Poll, of Melbourne. meditated homicide, which is no more acceptable under common law for doctors than for lay people, even if autonomously requested. If parliament decided that "to change the law would appear to be in keeping with the logic of respect for autonomy" a "special defence" would be needed which could then be pleaded in justification.

The Mental Health Act 1983 illustrates the advantages of statutory law in allowing doctors exceptional privileges while providing additional safeguards. It formally separates the responsibilities for an application for a section, the medica recommendations, and receipt by the hospital managers. A similar mechanism could be designed for euthanasia.

Freshfield Unit,

Brighton General Hospital,

Brighton BN2 3EW

1 Euthanasia around the world. BMF 1992;304:7-10. (4 January.)

2 Institute of Medical Ethics Working Party on the Ethics of Prolonging Life and Assisting Death. Assisted death. Lancel 1990;336:610-3.

3 Van der Maas PJ, van Delden JJM, Pijnenborg L, Looman CWN. Euthanasia and other medical decisions concerning the end of life. Lancet 1991;338:669-74.

4 Age Concern, Institute of Gerontology, and Centre of Medical Law and Ethics, King's College, London. The living will. London: Edward Arnold, 1988.

\section{Women in the NHS}

SIR, - It is worth remembering that 75 years ago on 13 February 1917, a small group of women doctors, finding that their applications for membership of the British Medical Association had been rejected because of their sex, founded the Medical Women's Federation. The active list of the General Medical Council now includes over 40000 women doctors. One quarter of general practice principals and over half of last year's entrants to medical school are women. Relations with the BMA have changed since 1917-two former presidents of the Medical Women's Federation have gone on to be presidents of the BMA, and there are close working relationships at officer level.

Caroline Langridge, head of the NHS women's unit, has indicated ways in which women capable of filling senior management posts can be brought forward. ' Positive discrimination is rightly unlawful, but positive action to identify and encourage talent is good sense. Applicable in management and nursing, it is equally applicable in medicine. In 1989 the Advisory Committee on Medical Manpower gave a figure of $£ 130000$ as the undergraduate training cost for one doctor. That figure must now be around $£ 160000$. A programme of positive action to ensure that the talent and training of young doctors - both men and women - is not wasted is overdue.

ELIZABETH SHORE

President, Medical Women's Federation, London WCIH 9JX

1 Dillner L. Where are the women in the NHS? BM I 1992;304: 399. (15 February.)

\section{Hospices and the NHS}

SIR,-Colin Douglas snipes again at the hospice movement in his brief article. ${ }^{\prime}$ In his novels his sourness of spirit can be amusing, but in this context I do not find it so.

I serve the Marie Curie Memorial Foundation in an honorary capacity, partly as a clinician and partly as an administrator. This charitable organisation functions in the field of cancer and is older than the NHS. In addition to education and research, we maintain a unique, nationwide home nursing service for patients with cancer as well as 